\title{
A Shift in Storytelling: Over the Garden Wall as a Literary Reconstruction of Dante's Divine Comedy
}

Un cambio en la narrativa: Over the Garden Wall como reconstrucción literaria de La Divina Comedia de Dante 


\section{Abstract}

Literature remains a field that serves TV creators and critics as a model both for influence and comparison. The continuity claimed by Thomas Doherty between the most recent TV narrative form with the serialised novels of Dickens or Wharton is not limited to the form itself but to its content as well. Such is the case of the TV animated miniseries Over the Garden Wall, created by Patrick McHale in 2014, whose combination of Victorian fairy-tale imagery and aesthetics, as well as its reliance on literary allusion incarnates this paradigm. Within its narrative there can be found an array of literary references that range from the classics to children's fables, as well as allusions to history and to different mythologies; an intertextual character that is featured in TV as much as in literary texts from all eras, binding the two forms together. Among the numerous texts referenced in this tale of tales, however, there is one that stands out: Dante Alighieri's Divine Comedy. This article scrutinises the relationship between Over the Garden Wall and Dante's Comedy, understanding the show's protagonist, Wirt, and his quest as a replication of Dante and his descent through Hell. The main claim is that by doing so, Over the Garden Wall also highlights how Campbell's narrative paradigm, applicable as it is to forms of media other than literature, evinces the narrative continuity, which exists between TV and the written text.

\section{Keywords: Over The Garden Wall, Divine Comedy, tv series, monomyth, intermediality.}

\section{Resumen}

La literatura sigue siendo un campo que sirve a creadores y críticos de televisión como modelo tanto de influencia como de comparación. La continuidad reivindicada por Thomas Doherty entre narrativa televisiva más reciente y las novelas serializadas de Dickens o Wharton no se limita a la forma en sí, sino también a su contenido. Tal es el caso de la miniserie de animación televisiva Over the Garden Wall, creada por Patrick McHale en 2014, cuya combinación de imaginario de cuentos de hadas y estética victoriana, asi como su dependencia de la alusión literaria, encarna este paradigma. Dentro de su narrativa se pueden encontrar un abanico de referencias literarias que van desde los clásicos hasta las fábulas infantiles, pasando por alusiones a la historia y a diferentes mitologías; un personaje intertextual que aparece tanto en la televisión como en los textos literarios de todas las épocas, uniendo ambas formas. Entre los numerosos textos a los que se hace referencia en esta serie animada, hay uno que se destaca: La Divina Comedia de Dante Alighieri. Este artículo analiza la relación entre Over the Garden Wall y La Divina Comedia, entendiendo al protagonista del programa, Wirt, y su búsqueda, como una réplica de Dante y su descenso al infierno. La afirmación principal es que, al hacerlo, Over the Garden Wall muestra cómo el paradigma narrativo de Campbell es aplicable a otros medios distintos de la literatura y evidencia la continuidad narrativa que existe entre la televisión y el texto escrito. 


\section{Introduction}

In the last few decades, the world has witnessed a surge of the popularity and impact of TV narratives, a growth that the Internet, thanks to broadcast streaming, has increased exponentially by offering these products to a globalised audience. If in 1992, Sarah Kozloff could already affirm that "Television is the principal storyteller in contemporary American society" (p. 67), the 21thcentury seems to be proving her correct; if anything, such a statement could be well made about any developed country. The appeal to a wider audience and the lure of profitability associated with it has not gone unnoticed by broadcasting companies, which have realised that audiences crave for content of quantity (i.e. the longevity of series and serials) ${ }^{1}$ and quality (i.e. narratives that are more impactful or complex). Such is the view of Jason Mittel, who sees the period from the "1990s to the present as the era of television complexity" (p. 29).

This increased complexity may finally serve to put to rest the last threads of reticence of the academy to tackle forms of popular media; a hesitance that should be by now over. Thirty years ago, Andreas Huyssen studied this discursive conflict between high and popular culture, which he termed "the Great Divide" (p. viii), the "categorical distinction between high art and mass culture" that was nourished in several periods of the 19th and 20th-century (p. xi). Huyssen claimed that the postmodern paradigm has challenged this dichotomy to the point of completely blurring the distinction between them (pp. ix-x), a fact that represents a facet of postmodernism's larger search for decentralization and "epistemology of difference" in which "the ideal of a rational, centred, and stable subject is exchanged for a protean, hybrid, multifaceted self-image." (Mendible, 1999, p. 72)

The same hybrid nature is to be found in serials, a medium that, although it has gradually developed a specific language and specific motifs, remains heavily indebted to "forms such as novels, films, videogames, and comic books" (Mittel, 2006, p. 30). Indeed, literature remains a field that serves TV creators and critics as a model both for influence and comparison. In that regard, in "Storied TV: Cable Is the New Novel", Thomas Doherty claims the kinship of the most recent TV narrative form with the serialised novels of Dickens, Trollope or Wharton (Doherty, 2012). However, the influence of literature on TV narratives cannot be limited to the form itself, as the content ought to be considered as well. Such is the case of the TV animated miniseries Over the Garden Wall, ${ }^{2}$ created by Patrick McHale in 2014, whose combination of Victorian and fairy-tale imagery as well as its reliance on literary allusion incarnates this paradigm.

The transformative and protean principles that Myra Mendible finds in postmodern fiction can be said to reside at the core of Over the Garden Wall's premise: a synthesis of several canonical figures, narratives and texts that are adapted to a format with a broad appeal, ready to be accessed and enjoyed. Among the numerous texts referenced in this tale of tales, however, there is one that stands out: Dante Alighieri's Divine Comedy. To those who are familiar with both works of fiction, this might not come as a surprise. As the analysis will presently evince, the parallelisms between

${ }^{1}$ Kozloff distinguishes serials, in which the story and discourse continue after the ending of each episode, from series, in which each episode has a self-contained plot, being the characters and the setting the thread of continuity (1992: 91). However, the author also points out that from 1980's both categories might be blurred in "hybrid" forms that combine the characteristics of both (Kozloff, 1992, p. 92). 
OTGW and Inferno are easy to notice and have indeed been outlined by the YouTube user TREY the Explainer, who on November-9th, 2015 published a video-analysis of OTGW that compares it to Dante's Inferno. However, while TREY just enunciates a systematic correspondence between each of the episodes of McHale's show with the sections and circles of Inferno (TREY the Explainer, 2015), the analysis here proposed goes beyond just showing the one-to-one relationships that appear between the series and Dante's text.

This perspective approaches the delineated relationship between the two texts from an academic stance in which the comparative analysis will be guided by Joseph Campbell's The Hero with a Thousand Faces, which studies the structure of the archetypal journey of the hero across numerous literary and mythological sources from different cultures, devising a narrative pattern composed by a series of stages common to all of these narrations. This study will trace the fundamental characteristics and stages of the hero's journey in relation to the Comedy in order to highlight the intimate relationship that exists between Dante's poem and OTGW. Given to the show's heavy reliance on literary allusion, other heroes and their journeys are integrated into OTGW's narrative. Consequently, the analysis will resort to Joseph Campbell's notion of the monomyth in which all of them, including Dante's, could be said to coalesce.

The objective of basing the analysis under Campbell's theoretical framework is to show how the reconstruction of the Divine Comedy is based on the general ideas proposed by Campbell in his text. We will see how Wirt and Dante fit into the same hero model, a hero that seeks the return to the straight path with beatitude as a guide through Inferno.

A synthesis between postmodern literary theory and Campbell's myth-criticism theory thus guides the development of the essay. The approach between the two theories will be carried out through the theoretical basis of Gérard Genette. Gérard Genette's concept of hypertextuality provides a theoretical framework for the comparative analysis between the Comedy and OTGW, which should not be studied merely as a show with nods and superficial references to a canonical literary work, but rather as reinterpretation of Dante's poem. According to Genette, "Hypertextuality refers to any relationship uniting a text $B$ (which I shall call the hypertext) to an earlier text A (I shall, of course, call it the hypotext), upon which it is grafted in a manner that is not that of commentary" (p. 5). Consequently, we argue that OTGW should be understood as a legitimate literary work that engages with the literary canon and re-signifies its hypotext into a new story, format and medium.

We must understand the added value within McHale's reconstruction of the Divine Comedy. While Dante's text is the hypotext, McHale's text (what we understand as hypertext) becomes not only the reinterpretation of Dante's text, but also, according to Genette's theory, there is a textual transcendence appearing the comedy within OTGW.

\section{Through the TV screen}

As a notorious part of the narrative of OTGW we can find a myriad literary reference that range from the classics and other canonical texts to children's fables, as well as allusions to history and to different mythologies. Among them, there are mentions of the wardrobe of C. S. Lewis' The 
Chronicles of Narnia, references to J.R.R. Tolkien's Middle Earth ${ }^{3}$ and to the story of Hansel and Gretel from the Grimms' Fairy Tales.

The intertextual connections established as a result of McHale's recursive use of allusions could be approached from various perspectives. The Comedy itself provides an easy parallel, as Dante's work is filled with references to authors, texts and literary characters, including Homer (Alighieri, 2008, p. 62) and Ulysses (Alighieri, 2008, p.157). Echoes of Dante and his pilgrimage, in turn, can be heard in hundreds of later texts thanks to the monumental influence of the Comedy on Western literary canon. For instance, Cervantes' Don Quixote, a text that is alluded to in the show, evinces in its first part similarities to Inferno (Avery, 1974-1975, p. 8 21). By multiplying the intertextual connections of the show, ${ }^{4}$ the latter add new meanings that expand or contrast the themes developed by McHale. For instance, Cervantes' Quixote and Homer's Odyssey are mentioned in an indirect form. Initially, this serves the narrative to pay homage to both texts with nods to their most famous episodes like that of the mermaids and Circe's pigs in the case of the former, or like Quixote's fight with the windmill, his knighting in the tavern or the inversion of roles between the two protagonists, in the latter's case.

These relations are, of course, inherent to the system of textual interface described by Kristeva and many other poststructuralists as the "intertext" (Kristeva and Moi, 1986, p. 37), a vision that conceives any work as a node in a completely integrated network. Albeit not related to poststructuralist theory, Joseph Campbell's The Hero with a Thousand Faces understands narratives in a similar way. Campbell describes the parallelisms that exist between multiple texts, myths, stories and legends concerning the journey that their protagonists follow in order to delineate a narrative thread into which all of them could be said to be subsumed. Campbell calls this pattern, which he finds to be present in the narrations of most cultures (p. 1), the monomyth, or the hero's journey. Given this model, Dante's voyage can be understood as one among many iterations of the monomyth, sharing the same characteristics and following the same series of stages that Campbell describes in his work. This is not surprising given the paradigmatic status of Dante's journey within Western culture, as argued by Harold Bloom, who deems it to be the second centre of his Western literary canon (p. 76). In fact, together with other works such as the Homeric epics, Dante's Divine Comedy is found within the framework of works that serve as source for other works. (Campbell, 2004, p.239).

OTGW begins with the narrator's voice-over describing the scenery of the tale, the Unknown. This wood is a place haunted by the souls of those who have lost their way and the region where the show's main antagonist, The Beast, dwells. Thus, two similarities between the work of Dante and McHale are already presented at the beginning: as the name itself suggests, The Beast can be understood as the equivalent of Lucifer, and the show's protagonist, Wirt, begins his journey wandering through the forest just as Dante begins his own, having lost his way in a great forest

\footnotetext{
${ }^{3}$ The allusion to Tolkien's work is reinforced by the fact that Elijah Wood, the actor who embodied Frodo in Peter Jackson's cinematic adaptation of The Lord of the Rings, gives voice to Wirt.

${ }^{4}$ The progressive inversion of the roles of Wirt and Greg is analogous to that of Sancho and Quixote, a process of influence and exchange known as "quijotización" (quixotization) in the case of the former and "sanchificación" (sanchification) in the latter's case, as described by Salvador de Madariaga (1972, pp. 127-135; 137-148).
} 
(Alighieri, 2008, p. 47). It is thus apparent that Wirt can be read as a replica of Dante, an idea that is underlined by several similarities between both characters, the first and most evident being that both are artists who glorify love and sing praises to their beloved, represented by Beatrice in the Comedy and Sarah in OTGW. Moreover, just as Virgil becomes Dante's companion in his journey through Hell and Purgatory, Greg, Wirt little brother, becomes his companion and guide through The Unknown, being the one who recognises the correct path that will lead both heroes to the encounter with The Beast and consequently, to the exit of the forest. Furthermore, just as Virgil is unable to continue the journey with Dante at the end of Purgatorio (Alighieri, 2008, p. 50 ), so is Greg at one point of the journey. Thus, even though initially the helper figure (Campbell, 2004, p. 66) seems to differ in qualitative terms, in the end the parallelism between Greg and Virgil can still be established, as both will guide the protagonists despite the motives that made them do so.

In the Comedy, only thanks to God's Will, realised in the dispensation granted by the intercession of Beatrice, St. Lucy and the Virgin, is Virgil able to leave Limbo at all (Alighieri, 2008, pp. 52-54). Albeit the parallelism of Dante's Hell and OTGW's The Unknown previously established seems to create a contradiction. However, to appreciate the parallels, one has to take into account the whole of the protagonists' journey. Dante's journey extends over a hundred cantos and three metaphysical realms, while Wirt's only stretches across a single region. Rather than adapting only elements of Dante's Inferno into its reconstruction of the text, OTGW synthesises and concretises elements taken from across all three parts of Dante's Comedy, since, as previously stated, OTGW is not a list of references, but a hypertext of the Comedy that goes beyond mere commentary of its hypotext as Genette's theory envisages.

Lastly, Dante's beloved, Beatrice, provides the most explicit parallel that can be drawn between both works, as another companion for Wirt and Greg, the bluebird Beatrice is introduced in the second episode of OTGW. Not only do both characters share the same name, but the choice of a bird as the embodiment of Dante's beloved Lady is consistent with Dante's metaphorical use of wings as a representation of the quality of blessedness that Beatrice epitomises (Alighieri, 2008, pp. 204, 212, 242, 244). However, McHale designs this character as an antithesis of her homonym, as throughout most of the journey, instead of guiding them to the exit of the Unknown, Beatrice will take Greg and Wirt along dangerous roads.

We can see how McHale's reconstructions pay attention to both a narrative level and a visual level, especially with the design of Wirt's character and the deconstruction within the reconstruction that he performs with Beatriz's character. And yet, as we will see in the following points, the comparison between the two texts is not limited to being single references, it becomes a reconstruction at a meta-narrative level.

\section{Between Dante and McHale}

Thus, once the comparison in between the construction of the characters of both works have been introduced, we will elucidate the points of connection that can be identified in particular sections and episodes of the show, approaching Wirt's journey through the framework of Campbell's monomyth. OTGW begins with the narrator's voice-over describing the scenery of the 
tale, the Unknown: "Somewhere lost in the clouded annals of history, lies a place that few have seen a mysterious place, called The Unknown where long-forgotten stories are revealed to those who travel through the wood." (McHale, 2013)5. Wirt, begins his journey wandering through the forest just as Dante begins his own, having lost his way in a great forest (Alighieri, 2008, p. 47). In the first episode of the series, "The Old Grist Mill", Greg and Wirt experience three different stages of the monomyth. In the beginning of the episode, the two brothers are lost in the woods, not knowing how they have ended up there or how to return home, which is their principal goal. Wirt fears that they will be condemned to wander in search for their path for all eternity. The situation in which Wirt and his brother, or even Dante for that matter, find themselves represents what Campbell calls the "Refusal of the Call" (Campbell, 2004, p. 53), in which the hero initially rejects the adventure or lacks the courage or resolution to start it. At the beginning of the first episode Wirt is in a state of fear because he doesn't know how they got lost in the forest and he doesn't know how to get out of there. The terror prevents him from moving forward and thinking clearly. He refuses to advance, refuses to accept the call to adventure. However, thanks to his guide and brother, they will continue on their way. As Campbell states: "[T] he subject loses the power of significant affirmative action and becomes a victim to be saved. His flowering world becomes a wasteland of dry stones and his life feels meaningless" (p. 54).

The second stage of the monomyth that appears in the first episode is the "Supernatural Aid" (Campbell, 2004, p. 63), the being that helps the hero in his adventure, which in the case of both works is represented by Beatrice. In the case of the Comedy, though Virgil might be considered to represent this role, he does so at the behest of Beatrice, who sends him to find and save Dante. In Wirt's journey, Beatrice, a talking bluebird, offers the travellers help in their attempt to exit the Unknown.

The third initial element of the monomyth is represented by The Woodsman, who acts as the forest warden with the aim of warning travellers about the Beast and the danger that it represents for wanderers like Greg and Wirt, as it devours the souls of the lost. As he warns the protagonist: "One last thing! Beware, the Unknown! Fear the Beast! And leave these woods! If you can. It is your burden to bear!" (McHale, 2014) In this way, The Woodsman bids the brothers farewell, foreshadowing that it will be a dangerous journey; a warning that does not discourage Wirt and Greg, however, who now do not refrain from accepting the call to adventure and cross the river. Taking all this into account, it is clear that The Woodsman embodies the role of the "Guardian of the Threshold" (Campbell, 2004, p. 71), the last trial that awaits the hero before his descent into the world of the numinous:

With the personifications of his destiny to guide and aid him, the hero goes forward in his adventure until he comes to the 'threshold guardian' at the entrance to the zone of magnified power. Such custodians bound the world in the four directions-also up and down-standing for the limits of the hero's present sphere, or life horizon. Beyond them is darkness, the unknown, and danger. (p. 71)

When the brothers cross the river and penetrate into the Unknown, they are fulfilling this essential

${ }^{5}$ This fragment belongs to the series' pilot episode, “Tome of the Unknown: Harvest Melody” that aired on September-9th, 2013. 
step in the hero's journey, the "Crossing of the First Threshold" (Campbell, 2004, p. 71). This is evident in the fact that McHale chooses the same word that Campbell uses in his description, "the unknown", for the realm in which the story takes place. In the Comedy, the threshold is of course represented by Hell's Gate, which also offers all travellers a warning before entering it (Alighieri, 2008, pp. 55-56).

After traversing the Vestibule of Hell and crossing the river Acheron in Charon's ship, Dante and Virgil reach the first of the circles of hell, Limbo. The souls that, like Virgil himself, inhabit it are not tormented like the sinners of other circles, yet they endure a similar condemnation. Their suffering stems from their longing and desire to join God and their awareness of the hopelessness of such endeavour. This eternal yearning places them in a state of hopeless "anaesthesia", as T. S. Eliot describes it (p. 256). Analogous to Limbo and the state of their inhabitants in OTGW is the quiet village of Pottsfield, where the events of the second episode, "Hard Times at the Huskin' Bee", take place. In Pottsfield, Wirt is seduced to choose a simple and quiet life, instead of continuing their journey through the following circles of The Unknown.

According to Campbell, "The idea that the passage of the magical threshold is a transit into a sphere of rebirth is symbolized in the worldwide womb image of the belly of the whale. The hero, instead of conquering or conciliating the power of the threshold, is swallowed into the unknown, and would appear to have died." (p. 83). If we consider Pottsfield under Campbell's theory, it can be identified as the "Belly of the Whale" (Campbell, 2004, p. 83) due to the impossibility, the difficulty, or unwillingness at the least, of getting out of it to continue the journey. Moreover, Campbell stresses the significance of renewal and rebirth, which are an integral part of this stage being the requirements for the adventure to continue. Pottsfield revolves around this idea, as anthropomorphic pumpkins, which are born after the bones of their previous selves have been unearthed, inhabit it. The two brothers will have to face the anthropomorphic pumpkins in order to move forward on the trip. It will not be a physical battle, but Wirt will have to fight the temptation to stay there forever. As Campbell explains: "Once having traversed the threshold, the hero moves in a dream landscape of curiously fluid, ambiguous forms, where he must survive a succession of trials [...]. The hero is covertly aided by the advice, amulets, and secret agents of the supernatural helper whom he met before his entrance into this region." (Campbell, 2004, p. 89)

The following circle that Dante visits is where the lustful sinners are tormented and in OTGW it finds its parallel in the episode "Schooltown follies" and in its main side character, Miss Langtree. This schoolteacher is obsessed by the infidelity of his boyfriend Jimmy Brown to the point of being unable to teach. The fact that unfaithfulness and a couple are the main elements of this episode might serve to draw another connection with the Comedy, albeit not exactly the same, as the most noteworthy episode in the second circle is Dante's meeting with Francesca and Paolo, two adulterous lovers.

The set of trials and deeds that the heroes will have to face is comprehended within the first step of the journey's beginning and right after the crossing of the forest's threshold. The array of tests that Greg, Wirt and Beatrice are facing are included from this episode up to the end of "Mad Love": the heroes will have to solve or complete a series of feats and tasks, which falls in line with Campbell's description of the hero's adventures. 
In the fourth episode, "Songs of the Dark Lantern", Wirt, Greg and Beatrice visit an inn that corresponds to the third circle of hell in the Comedy, that of the gluttons. In this level, gluttons are battered down by heavy rains and hail storms, which, alongside the terrible barking of Cerberus, who guards the third circle, results in a din that drowns the cries and screams of the tormented (Alighieri, 2008, p. 70). In this fourth episode, due to a storm that is heard continuously, OTGW's heroes will not be able to advance their journey and will have to wait in a bar whose door is protected by a dog just as Cerberus guards the third circle, whose sinners are tormented by heavy rainfalls. It also worth mentioning how, in several moments of the episode, Greg appears in the background with all kind of meals. This characteristic is never used again in the series and it is nothing but a reinforcement of the reconstruction of the episode as the circle where gluttons are punished. Moreover, in this episode Wirt is referred to as "a pilgrim, you're a traveller on a sacred journey" (McHale, 2014). It is here too that Wirt is officially named a hero; one who must complete a quest in which the love for his brother and for Sara will guide him through the darkness.

The fourth circle is where those whose attitude towards possessions deviates from morally acceptable standards are suffering: the moneygrubbers, who accumulated wealth, and the wasters that squandered it. For their punishment both groups partake in a dance in which each sinner has to carry a heavy weight around a circle (Alighieri, 2008, p. 73). The protagonist of "Mad Love", the series' fifth episode, is Quincy Endicott, an old English Lord who has devoted his life to commerce, specifically that of tea. His wealth is matched only by his solitude, the very representation of the weight carried by the wasters and moneygrubbers around the circle in the Comedy. By the end of the episode, Greg receives two gold coins that he is supposed to use for paying the fare of the river ferry. This, of course, constitutes a reference to the fare paid to Charon for the safe crossing of the recently dead through Styx in Greek mythology. It reinforces the understanding of the episode as a recreation of the fourth circle of hell, since, shortly after, the travellers reach Styx, the lagoon that Dante represents in the Comedy as the fifth circle of hell (Alighieri, 2008, p. 76). Despite their tremendous significance, Greg throws the coins away: he is aware that, allegorically, accepting them would mean their death and the end of their journey. This difference reveals the significance of Gennete's hypertext theory: OTGW is clearly not a mere repetition of its hypotext.

The subsequent episode, "Lullaby in Frogland", begins with Wirt, Greg and Beatrice sailing across a river on a ship manned by a crew of toads, thus continuing the intertextual construction established at the end of the previous episode. This river is, then, a reference to Styx, the lagoon in which the angry and the sullen are eternally drowned in muddy waters as their punishment in the fifth circle of hell (Alighieri, 2008, p. 76). By the episode's conclusion, the ship reaches its destination and, after mooring the vessel, all the crew plunges into the mud, thus reflecting the punishment of the damned in this circle.

Dante's landing is much more macabre, arriving at the City of Dis, the walled frontier between Upper and Lower Hell that also serves as entrance to the sixth circle, where heretics are tormented by being buried and burned in open tombs (Alighieri, 2008, p.84). In OTGW, this heresy is reflected in two forms: by the use of the figures of witches and evil spirits, who incarnate the deviation from God, and by the themes of oppression and rebellion. These two are woven together in Wirt's and Greg's adventures in "Lullaby in Frogland" and in the subsequent episode, "The Ringing of 
the Bell." In the former, right after leaving the lagoon and its mud, Greg and Wirt realise that Beatrice has flown away and, following her, they end up in a witch's house whose owner, Adelaide, had made a pact with Beatrice to enslave the kids in return for lifting her family's curse and restore herself and her parents to their human form. Rebellion is represented both by Lorna -Adelaide's niece- and her desires to be freed from her aunt's magic control, and by Wirt and Greg, who devise a plan to liberate Lorna. However, by doing so they set free the demon that lies within Lorna. It comes to possess her completely until it is finally exorcised. "The Ringing of the Bell" can be linked to another stage of Campbell's hero's journey:

The crux of the curious difficulty lies in the fact that our conscious views of what life ought to be seldom correspond to what life really is. [...] there is experienced a moment of revulsion: life, the acts of life, the organs of life, woman in particular as the great symbol of life, become intolerable to the pure, the pure, pure soul. The seeker of the life beyond life must press beyond (the woman), surpass the temptations of her call, and soar to the immaculate ether beyond. (pp. 111-112)

Campbell here speaks rather of a temptation of a physical and pleasurable nature that can invite the hero to divert from his quest or abandon it altogether, but Wirt's conception of love differs significantly. His view of love is based on the medieval ideal of courtly love that was the foundation of the Provençal Fin'amors, but that was also a prominent trope in mystic poetry (De Rougemont, 1983, p. 166). Both are integral to Dante's poetry. Thus, in tune with OTGW's re-creation of Inferno, the representation of the female figure in the series is not effected at a physical but rather at a spiritual level, becoming the motivation for the hero's journey.

In "Babes in the Wood", Wirt loses hope and gives up, allowing The Beast to claim him, gradually becoming part of a tree as he falls asleep in the snow. This corresponds to those souls who, in despair, commit suicide and are turned into trees in the seventh circle of hell in Inferno (Alighieri, 2008, p. 98). In this episode, several stages of Campbell's hero's journey take place, the first of them being the "Meeting With the Goddess": "The ultimate adventure, [...] is commonly represented as a mystical marriage of the triumphant hero-soul with the Queen Goddess of the World. This is the crisis at the nadir, the zenith". (Campbell, 2004, p. 100) Greg meets the Queen of the Clouds, who for his help grants him a wish. Greg's request to return home, however, cannot be fulfilled, as Wirt is far too lost to be able to find a way back. Greg then asks the Queen to allow him take his brother's place. Greg's sacrifice corresponds to the hero's "Apotheosis" (Campbell, 2004, p. 138), which occurs when a character physically or metaphorically dies to live in spirit, transmuted into a state of divine knowledge that serves as preparation for the hero's return. As Campbell asserts: "Those who know, not only that the Everlasting lies in them, but that what they, and all things, really are is the Everlasting, dwell in the groves of the wish fulfilling trees, drink the brew of immortality, and listen everywhere to the unheard music of eternal concord." (p. 154)

Considering that most of the action in "Babes in the Wood" takes place in the realm dreamt by Greg, it is clear that the whole episode represents his inner death to spiritually live in this realm and thus be able to contact the divine, paving the way for the restoration of his brother. This, in turn, constitutes the last step in this chapter of the hero's journey, the "Ultimate Boon", the definitive gift that enables the achievement of the quest's goal. Greg is granted this possibility as a reward for his efforts and his sacrifice, while all the steps he has taken up to this point were 
a preparation and a purification to receive this gift: the wish granted by the Queen of the Clouds that will free Wirt and open the way for the brothers' eventual return to their home. As Campbell contends: "The gods and goddesses then are to be understood as embodiments and custodians of the elixir of Imperishable Being but not themselves the Ultimate in its primary state. What the hero seeks through his intercourse with them is therefore not finally themselves, but their grace, i.e., the power of their sustaining substance." (p. 168)

Episode nine, "Into the Unknown", has great symbolic significance and thus the analysis will approach it in two separate parts to bring out the analogy with the Comedy as clearly as possible, with the first considering elements of the real world and the second focusing only on the Unknown. The episode is a flashback to the series of events that led Wirt and Greg to be stranded in the Unknown during the night of Halloween. The night of Halloween, understood as a night of impostors and disguises, becomes analogous to the arrival in the eighth circle of hell. In the Comedy, Dante and Virgil descend a ravine (Alighieri, 2008, p. 117-118), while in the brother's case the descent is a consequence of a manoeuvre to avoid being hit by a train. In Dante's eighth circle, the hypocrites are tortured; a characteristic that in OTGW can be attributed to Wirt, because he constantly blames his brother for their misfortunes. The flashback, which reveals how Wirt's poor choices and cowardice led them to the Unknown, provides the first step of the quest, the "Call to the Adventure" (Campbell, 2004, p. 45). The brothers, following Wirt's crush, Sara, go to a cemetery to celebrate a Halloween party, but the arrival of the police frightens them. In their escape they jump over the cemetery wall-which could be deemed an eternal garden-and almost get hit by the train and tumble into a lake. When they wake up, they find themselves in the Unknown which closely corresponds to Campbell's definition of said space, a place that will always be unfamiliar, found in a distant land, to which the hero will get on his own or carried by a benign or a malignant agent (Campbell, 2004, p. 53).

The evil agent that Campbell mentions can be identified with the train in this scenario, as it constitutes the pivotal event that brings about the required conditions for the brother's involuntary entry into the fantasy world of the Unknown. The fall into the lake and into unconsciousness is in fact paradigmatic in many journeys of heroes, serving as the nexus between the ordinary world and the realm of the numinous. It is at this point when the "Departure" (Campbell, 2004, p. 45) is complete, as the hero's figure has been consolidated and the adventure and the initiation of the hero are about to commence. After the events of the ninth episode, the story is connected with the beginning of the show and the two protagonists' wandering through the forest.

In the last episode, "The Unknown", Greg and Wirt are about to conclude their adventures in their exit from their personal Inferno. Before that, however, there is one last stage in their journey, analogous to the ninth circle of hell, that of traitors (TREY the Explainer, 2015). At last, The Beast can be seen entirely; a being whose representation is characterised by satanic motifs, both in narrative and visual terms: its horns, its deceitfulness and its body composed by dozens of sorrowful faces. This last element is directly analogous to Dante's unorthodox representation of Satan as a being with three faces (Alighieri, 2008, p. 192).

Just as in "Babes in the Wood", "The Unknown" comprises several stages of the monomyth, starting with the "Rescue from Without" (Campbell, 2004, p. 192): “The hero may have to be brought back 
from his supernatural adventure by assistance from without. That is to say, the world may have to come and get him. For the bliss of the deep abode is not lightly abandoned in favour of the self-scattering of the wakened state." (p. 192)

In the case of Wirt and Greg, it is a hand that serves as external assistance, rescuing them from drowning in the lake as happens in several other narratives of heroes discussed by Campbell. Thus, they cross the threshold that initially took them to their adventures and now return from it, with the water serving as the frontier between both worlds. Unlike Wirt, Greg feels comfortable both in the real world and in the Unknown. That is why the stage of "Master of Two Worlds" (Campbell, 2004, p. 212) affects Wirt especially in that it signifies the achievement of equilibrium between the real and the fictitious. After the journey the hero feels at ease and competent in the inner world as much as in the exterior: "Freedom to pass back and forth across the world division, from the perspective of the apparitions of time to that of the causal deep and back [...] is the talent of the master. [...] he no longer tries to live but willingly relaxes to whatever may come to pass in him; he becomes, that is to say, an anonymity." (Campbell, 2004, p. 212)

The last step of the hero's journey is the hero's "Freedom to live" (Campbell, 2004, p. 221). In this particular work, it is clear that the adventure has led not only Greg and Wirt but also all characters that have accompanied them to a state in which they can freely enjoy their lives. Life can now be understood as the enjoyment of each moment, without anticipating the future or regretting the past. Beatrice and her family regain their humanity, the Woodsman recovers his daughter and Wirt manages to become romantically involved with Sara. With this, the heroes reach the end of their journey both at a physical level and at a personal level. The hospital bed where Wirt wakes up feels like a bonfire, a warm and close place, surrounded by friends and family all worried about him. The real world will no longer be distant and dangerous because he left as a mediocre character, but he has made himself anew along the way.

\section{Conclusion}

Throughout these pages, Brian McHale's Over the Garden Wall has been read as a text that can be understood as a literary work sourced in the Divine Comedy by Dante but developing the motifs, settings, structure and narrative thread of the hypotext into a new story and format, suited to the specificities of its medium. As is the case of thousands of mythological and literary narratives, the Comedy itself among them, OTGW follows the narrative pattern described by Joseph Campbell in The Hero with a Thousand Faces, the monomyth or the journey of the hero, as Wirt and Greg's voyage through the Unknown reflects most of the stages proposed by Campbell. The analysis has shown how OTGW transcends a simple enumeration of nods and references to Dante's work, being instead a reinterpretation of its hypotext. And thus, this is why this analysis was necessary. While other comparisons were an enumeration of one-to-one references, here we have seen a deeper connection between both texts.

In its relation to both the Comedy and the monomyth, OTGW evinces its allegiance to literature by not being shy to engage with seminal works of the literary canon, synthesizing some of its motifs to create a new text in a different medium. In addition, the nexus between the different theoretical 
frameworks used in the present study has been the concept of hypertextuality developed by the poststructuralist critic Gérard Genette.

Therefore, as the journey of the hero comes to full circle, the story of the brothers fits within Campbell's paradigm. However, unlike the examples provided by Campbell, this story makes use of a new and less explored format, animated cartoons, an incipient format that is progressively gaining traction and complexity. This significance needs to be attributed in part to the central role of TV as a source of entertainment in our contemporary globalized culture, which has resulted in the increasing acceptance of television as a medium and a field of study worthy of academic attention since the last decades of the 20th-century. "Television, which claims to record reality, creates it instead. We are getting closer and closer to the point where the social world is primarily described-and in a sense prescribed-by television" (Bourdieu, 1994, p. 22). Like literature or cinema before it, television has become one of the principal engines for the creation of narratives that not only are a reflection of past texts or of our social context but that shape our understanding of reality itself. Narratives have experienced a radical change during the past few decades as the new forms of media are no longer limited to a local or national background; thanks to the Internet and globalization, TV's newly crafted narratives have a global reach that allows them, and their hypotexts, to be consumed by audiences of diverse cultural backgrounds.

Thus, Genette's theory remains as a constant throughout the whole analysis: the hypertext relationship that includes a text $A$ (the hypotext, in this case the Divine Comedy) within a later text $B$ (called hypertext or for the analysis: OTGW). Genette becomes a synthesis between postmodern literary theory and Campbell's myth-criticism theory. Therefore, the idea of introducing a double theoretical framework serves as a reinforcement to demonstrate the reconstruction of Dante's text within McHale's text.

As Sarah Cardwell writes: "There is no ontological or medium-specific reason why a true artwork cannot exist within the medium." (Cardwell, 2013, p. 30) That is to say, the medium in which a text is shaped does not impair the artistic merit of the work. Thus, as has been delineated throughout the analysis, the miniseries follows a narrative rhythm that creates new notes and adapts old melodies. The resulting composition is not marred at any time by its format and medium. Over the years, many other literary media like comic books have been regarded as second-rate literature on the assumption that there is greater importance in form than in meaning. With OTGW, McHale has been able to knock down those preconceptions, showings that a well-crafted narrative enriched by hundreds of canonical texts is above any format, allowing the audience to conclude that OTGW can be enjoyed as an actual literary work.

\section{Referencias bibliográficas}

Alighieri, Dante, David H. Higgins (ed.) (2008). Divine Comedy. Traducción de Charles H. Sisson. Oxford: Oxford UP.

Avery, William T (1974-1975). Elementos Dantescos del Quijote. Anales cervantinos 13-14 : 3-36. 
Bloom, Harold (1994). The Western Canon: The Books and Schools of the Ages. New York: Harcourt Brace.

Bourdieu, Pierre (1994). On Television. Traducción de Priscilla Parkbust Ferbuson. New York: The New Press.

Campbell, Joseph (2004). The Hero with a Thousand Faces. Commemorative Edition. Princeton: Princeton UP.

Cardwell, Sarah, Jacobs Jason, y Peacock Steven (eds.) (2013). Television Aesthetics: Stylistic Analysis and Beyond. Television Aesthetics and Style (pp. 23-44). London: Bloomsbury

De Rougemont, Denis (1983). Love in the Western World. Traducción de Montgomery Belgion. Princeton: Princeton UP.

Doherty, Thomas (2012). "Storied TV: Cable Is the New Novel" The Chronicle of Higher Education. Chronicle. Recuperado de https://www.chronicle.com/article/Cable-Is-the-NewNovel/134420.

Eliot, T. S (1991). Dante. Selected Essays (pp. 237-277). London: Faber \& Faber.

Genette, Gérard (1997). Palimpsests: Literature in the Second Degree. Traducción de Channa Newman y Claude Doubinsky. London: University of Nebraska Press.

Huyssen, Andreas (1986). After the Great Divide: Modernism, Mass Culture, Postmodernism. Indianapolis: Indiana UP.

Kozloff, Sarah y Allen, Robert (ed.) (1992). "Narrative Theory and Television" Channels of Discourse, Reassembled: Television and Contemporary Criticism. The University of North Carolina Press.

Kristeva, Julia, y Toril Moi (1986). The Kristeva Reader. New York: Columbia UP.

Madariaga, Salvador de(1972). Guía del lector del Quijote. Buenos Aires: Editorial Sudamericana. Mchale, Patrick (2013). Tome of the Unknown: Harvest Melody. Cartoon Network Studios.

Mchale, Patrick (2014). Over the Garden Wall. Cartoon Network Studios.

Mendible, Myra (1999). High Theory/Low Culture. Postmodernism and the Politics of Carnival. Journal of American Culture, 2, 71-76.

Mittel, Jason (2006). Narrative Complexity in Contemporary American Television. The Velvet Light Trap, 58, 29-40.

Trey the Explainer (9.11.2015). Over the Garden Wall is Dante's Inferno (Symbolism Analysis). YouTube. Recuperado de https://www.youtube.com/watch?v=MBg8tQvATIA. 